\title{
Response of Maize Hybrid to Biofertilization, Soil Nitrogen Application and Weed Control
}

\author{
Radwan, F.I. and M.A.A. Nassar ${ }^{1}$
}

\begin{abstract}
Two field experiments were carried out at the Experimental Farm of the Faculty of Agriculture (Saba Basha), Alexandria University, during 2007 and 2008 summer seasons. This study was conducted to investigate the effect of biofertilization, VA-mycorrhizal inoculation, soil nitrogen application and weed control on growth attributes, yield and yield components of maize hybrid cultivar, namely, three-way cross 310 (T.W. C. 310).

The obtained results indicated that the combined treatment of VAM-fungi, and cerealen bio-fertilizers supported by $105.0 \mathrm{~kg} \mathrm{~N} / \mathrm{ha}$, had positive significant effects on all the studied characters.

The combination of VA-mycorrhizal and biofertilizer of cerealen in addition to a rate of $105.0 \mathrm{~kg} \mathrm{~N} / \mathrm{ha}$, was the best treatment to obtain the highest growth attributes, yield, yield components and weed characters of T.W.C.310.The highest grain yield/ha, total dry weight and weed characters were obtained from hand hoeing twice, atrazine inoculation with VA-mycorrhiza, biofertilizers cerealen and fertilized with $105.0 \mathrm{~kg} \mathrm{~N} / \mathrm{ha}$.
\end{abstract}

Key words: Nitrogen application, T.W.C310, Cerealen, Mycorrhiza, Atrazine, Hand hoeing, Weed control.

\section{INTRODUCTION}

Corn (Zea mays, L.) is one of the most important cereal crops in Egypt and the world. It is used for bread industry (mix $80 \%$ wheat flour with $20 \%$, maize flour) in order to reduce wheat importation and animal feeding. Increasing maize production depends upon many factors. Nitrogen fertilizer level is considered among the most important factors affecting maize plant.

Some growth and yield characters were affected by application of nitrogen fertilizer (Radwan, 1998; Soliman et al.. 2001; El- Moselhy and Zahran, 2003; Nofal and Mobarak, 2003 and Gomaa, 2008).

Biofertilizers drew the attention as a partial part goal alternative to $\mathrm{N}$ fertilizer application. In addition, biofertilizers have many advantages i.e. supply part of plant N. requirement by $25 \%$, increase the availability of nutrients, reduce the environment pollution, control the vegetative growth and improve the yield potential (Inderjit and Dakshini, 1997; Chunchun et al., 1998; Saad and Ahmed, 2002; Cocking, 2003 and Gomaa, 2008). Inoculation of corn seeds with VAM mycorrhizae could supply the plants with apart of

${ }^{1}$ Plant Production Dept., Fac. of Agriculture,

Saba Basha, Alexandria University

Received October 25, 2011, Accepted December 26, 2011. nitrogen required and could increase grain yield, its attributes and chemical composition (Radwan, 1998; Ahmed et al.. 2003; Virendra and Ahlawat, 2004 and Mekail et al.. 2005).

Weeds are one of the most important factors in maize production. They cause important yield losses worldwide with an average of $12.8 \%$ despite weed control application and $29.2 \%$ in the case of no weed control (Hussein, 1996 and Mosalem and Shady, 1996).

Therefore, weed control is an important management practice for maize production that should be carried out to ensure optimum grain yield (Dogan et al.. 2004; David et al.. 2005 and Abo Ziena et al . 2008). Weed control in maize is carried out by mechanical and/or chemical methods.

Therefore, the aim of this study was to investigate the response of maize hybrid to biofertilization, soil nitrogen application and weed control on growth and yield of corn plant (Zea mays, L.).

\section{MATERIALS AND METHODS}

Two field experiments were carried out, at the experimental Farm, of the Faculty of Agriculture. (Saba Basha), Alexandria University, at Abees-Alexandria, Egypt, during the two successive summer seasons of 2007 and 2008. The experimental design was a split plot with four replicates; the main plots were conducted for the Bio-nitrogen fertilization treatments 1) Uninoculation $+140 \mathrm{~kg} \mathrm{~N} / \mathrm{ha}, 2$ ) Cerealen $+105.0 \mathrm{~kg}$ $\mathrm{N} /$ ha, 3) A-mycorrhizae $+105.0 \mathrm{~kg} \mathrm{~N} / \mathrm{ha}$ and 4) Cerealen + A-mycorrhizae $+105.0 \mathrm{~kg} \mathrm{~N} / \mathrm{ha}$. Nitrogen fertilizer was applied in the form of urea $(46 \% \mathrm{~N})$ was applied at the abovementioned levels after sowing and just before the sowing, seed treatment with mycorrhizae spores, A-mycorrhizae inoculation was prepared and added as described by Radwan (1996). Local strain of Glomus macrocarpum was obtained from Plant Production, Department, Faculty of Agriculture (Saba Basha), Alexandria University, Alex., Egypt. Cerealen (Azospirillum brasilense) was produced by general Organization for Agric. Equalization. Fund. Ministry of Agriculture. The sub-plots were assigned to four weed control treatments; 1) Unweeded (control), 2) hand hoeing twice, 3) atrazine (Gesapium 80\%, W.P.) [2chloro-4-ethylamino-6-15 opropylamino S-traizain) was applied at a rate of $2.38 \mathrm{~kg} / \mathrm{ha}$ applied as a pre- 
emergence treatment (A-PE) and 4) Atrazine plus one hand hoeing. The experimental soil was clay loam in texture, poor in organic matter $(0.90 \%$ with $\mathrm{pH} 8.0$. Available phosphorus was $0.41 \mathrm{mg} / \mathrm{kg}$ and available nitrogen was $0.42 \mathrm{mg} / \mathrm{kg}$

Grains of corn (Zea mays, L.) hybrid are three ways cross 310 (T.W.C. 310). The sowing dates were 15 May and 1 June in 2007 and 2008 seasons, respectively. The area of each sub-plot was $10.5 \mathrm{~m}^{2}(3 \times 3.5 \mathrm{~m})$ with five ridges $60 \mathrm{~cm}$ apart, the sowing distance was $30 \mathrm{~cm}$ between hills. The normal cultural practices were carried out as recommended in the vicinity.

Fresh root samples, at vegetative growth stage were stained with trypan blue (Phillips and Hayman, 1970). At 55, 75 and 95 days after sowing, ten guarded plants were taken at random from each treatment. The following morphological and growth characteristics were recorded:

1. Plant height $(\mathrm{cm})$.

2. Stem diameter $(\mathrm{cm})$.

3. Leaf area index (LAI).was computed according to the formula of (Watson 1952):

$(\mathrm{LAI})=$ Unit leaf area / Unit ground area

4. Dry weight/plant (g). Was computed according to drying to a constant

Weight in forced draft air oven at $70 \mathrm{c}$ and the dry weight was recorded.

5. Crop growth rate (C.G.R.). Was computed according to the formula Suggested by Brown (1984)

(C.G.R.) = W2-W1/S A (t2-t1) where

$\mathrm{W} 2, \mathrm{~W} 1$ are plant dry weight at time one $\mathrm{T} 1$ and time two T2

Corresponding days.

$\mathrm{SA}=$ the soil area occupied by the plant at each sampling.

6. Relative growth rate (R.G.R.). Was calculated according to the formula of (Watson 1952). (R.G.R.) = Log W2- log W1/t2-t1.

At harvesting the following yield and its components were recorded:

1. Ear length $(\mathrm{cm})$

3. Ear diameter $(\mathrm{cm})$

2. Ear height $(\mathrm{cm})$

4. Number of rows/ear

5. Number of grains/row

6. Weight of grains /ear (g)

7. 100-grain weight (g)8. Grain yield (ton/ha.)

Weed characters were recorded at 55 and 75 days after sowing where weeds were hand pulled from one square meter taken at random in each plot and classified into different species. For each species the number and dry weight of weeds (at $70^{\circ} \mathrm{C}$ for 48 hours) were recorded.

Data of growth characters, yield components and weed characters were statistically analyzed using split plot design according to the method described by Snedecor and Cochran (1982). The means were compared using L.S.D. values at 5\% level.

\section{RERSULTS AND DISCUSSION}

\section{A. Effect of fertilization}

Data in Tables 1 and 2 showed that plant height, stem diameter, leaf area index, total dry weight, crop growth rate and relative growth rate at the three growth stages in the two growing seasons of 2007 and 2008 were affected by treatment of A-mycorrhizae +105.0 $\mathrm{kg} \mathrm{N} / \mathrm{ha}$. The enhancement of nutrient uptake and its translocation increased photosynthetic rate and accumulation of photosynthesis in shoots (Radwan, 1998). These results are in agreement with those obtained by Ahmed et al.. (2003) on faba bean, chickpea and lupine plants, El-Moselhy and Zahran (2003) on barley, Virendra and Ahlawat (2004) on maize Ogut et al.. (2005) on wheat.

Data in Tables ( 3 and 4 ) showed that yields obtained by combined treatment (Cerealen + A-mycorrhizae + $105.0 \mathrm{~kg} \mathrm{~N} / \mathrm{ha}$.) were significant higher than those of the other treatments. Ear length, ear height, ear diameter, number of rows/ear, number of grains/row, weight of grain/ear, weight of 100 grain and grains yield (ton/ha), were significantly increased by the combination ; Cerealen + A-mycorrhizae $+105.0 \mathrm{~kg}$ $\mathrm{N} /$ ha.. The highest values of 100 grain weight were 38.88 and $36.55 \mathrm{~g}$ with Cerealen + A-mycorrhizae + $105.0 \mathrm{~kg} \mathrm{~N} / \mathrm{ha}$ compared with 37.37 and $33.78 \mathrm{~g}$ control $+140 \mathrm{~kg} \mathrm{~N} / \mathrm{ha}$, in the two seasons, respectively. It can be stated that the treatment: Cerealen and Amycorrhizae inoculation had promoted the production of maize grains. Similar results were obtained by ElKhawas (1990), Mekail et al.. (2005), Ogut et al.. (2005) and Gomaa (2008) however, once roots emerge at seed germination and are colonized by Arbuscular and microorganisms, energetic pathways such as glycolysis and conversion of conjugate indol acetic acid (IAA) to active IAA are stimulated. Also, the mycorrhizae spores and microorganisms increases the synthesis of the endogenous photo hormones which play an important role in formation of a big active root system that allow more nutrients uptake and hence may promote many of bioactions processes. 


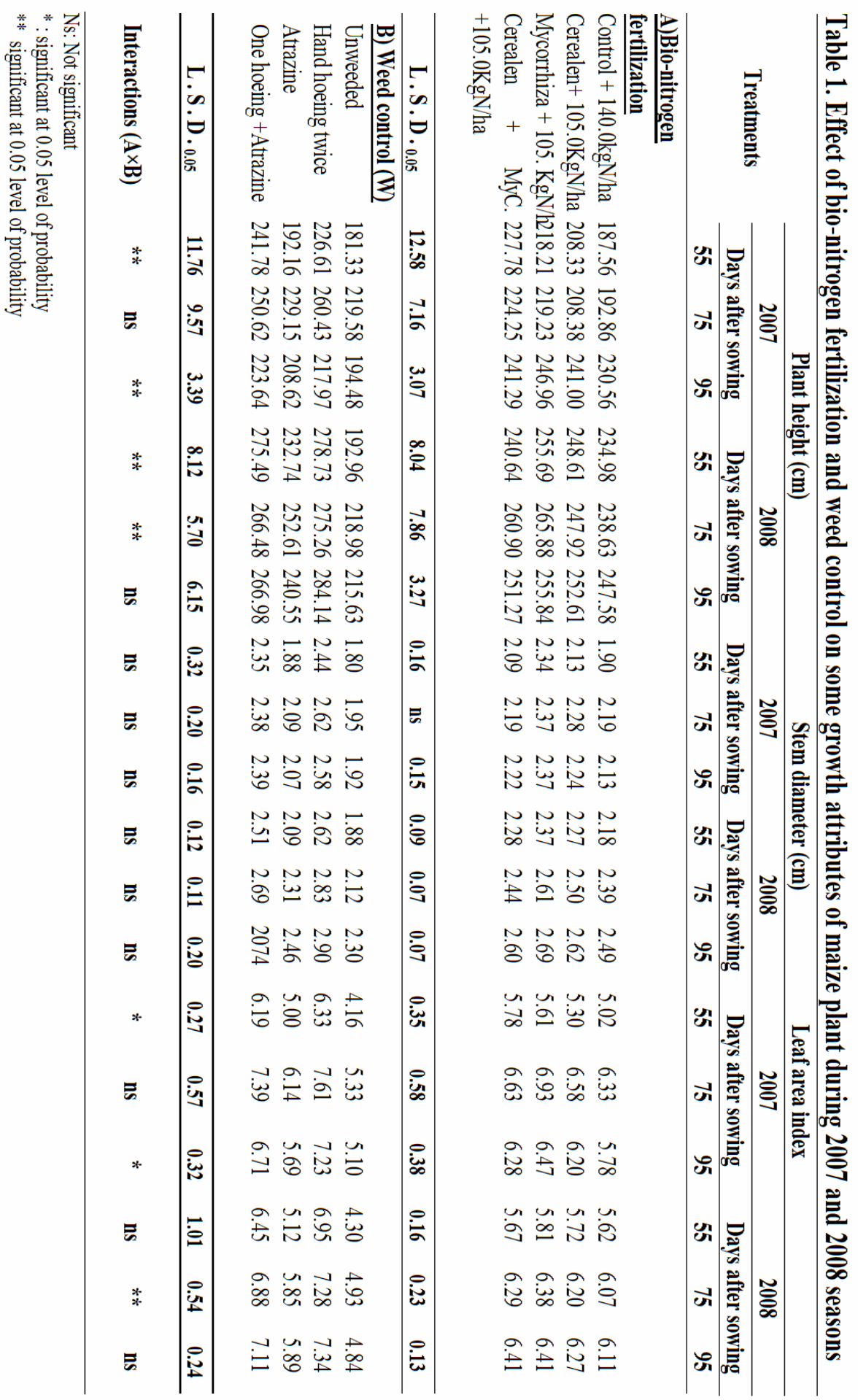




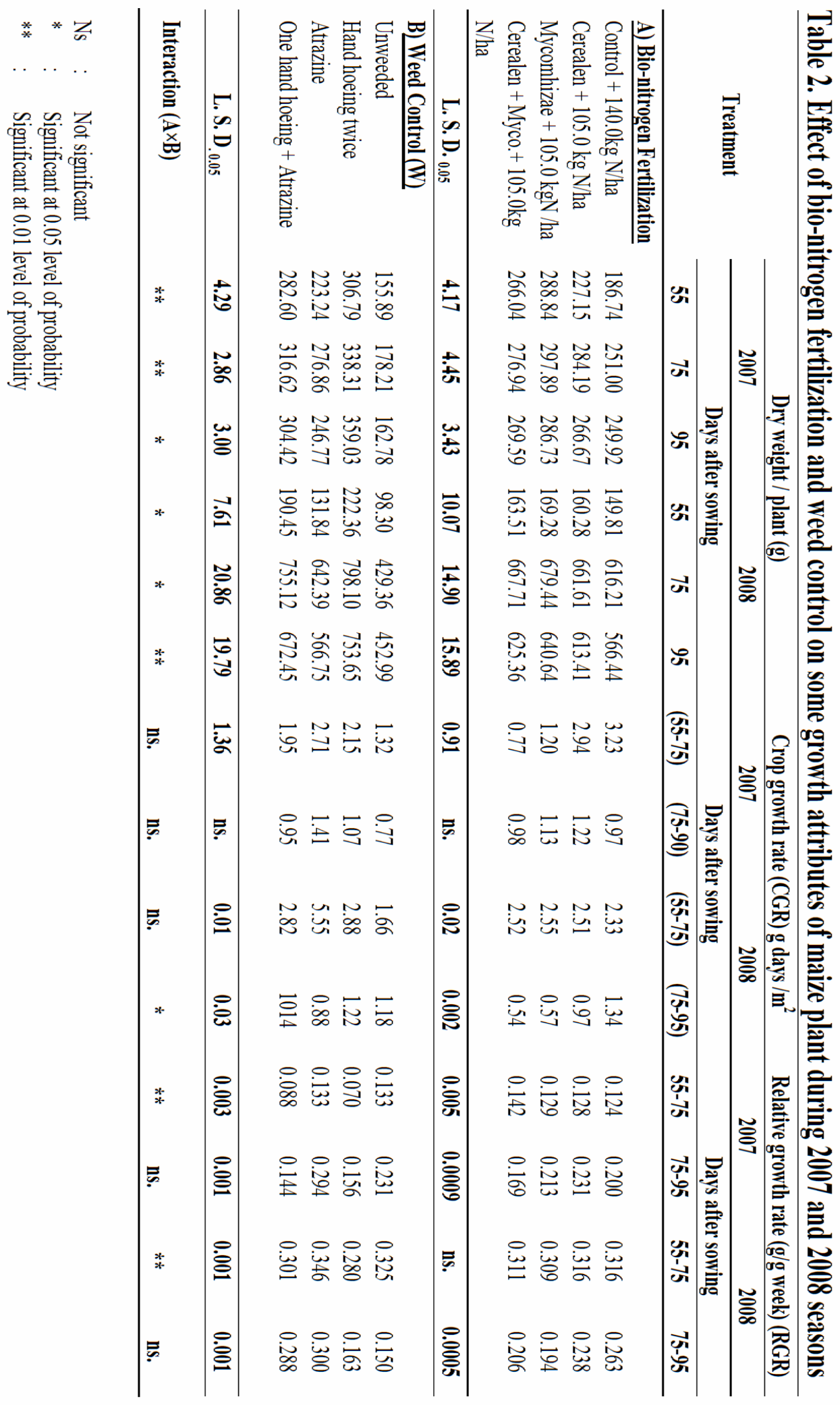




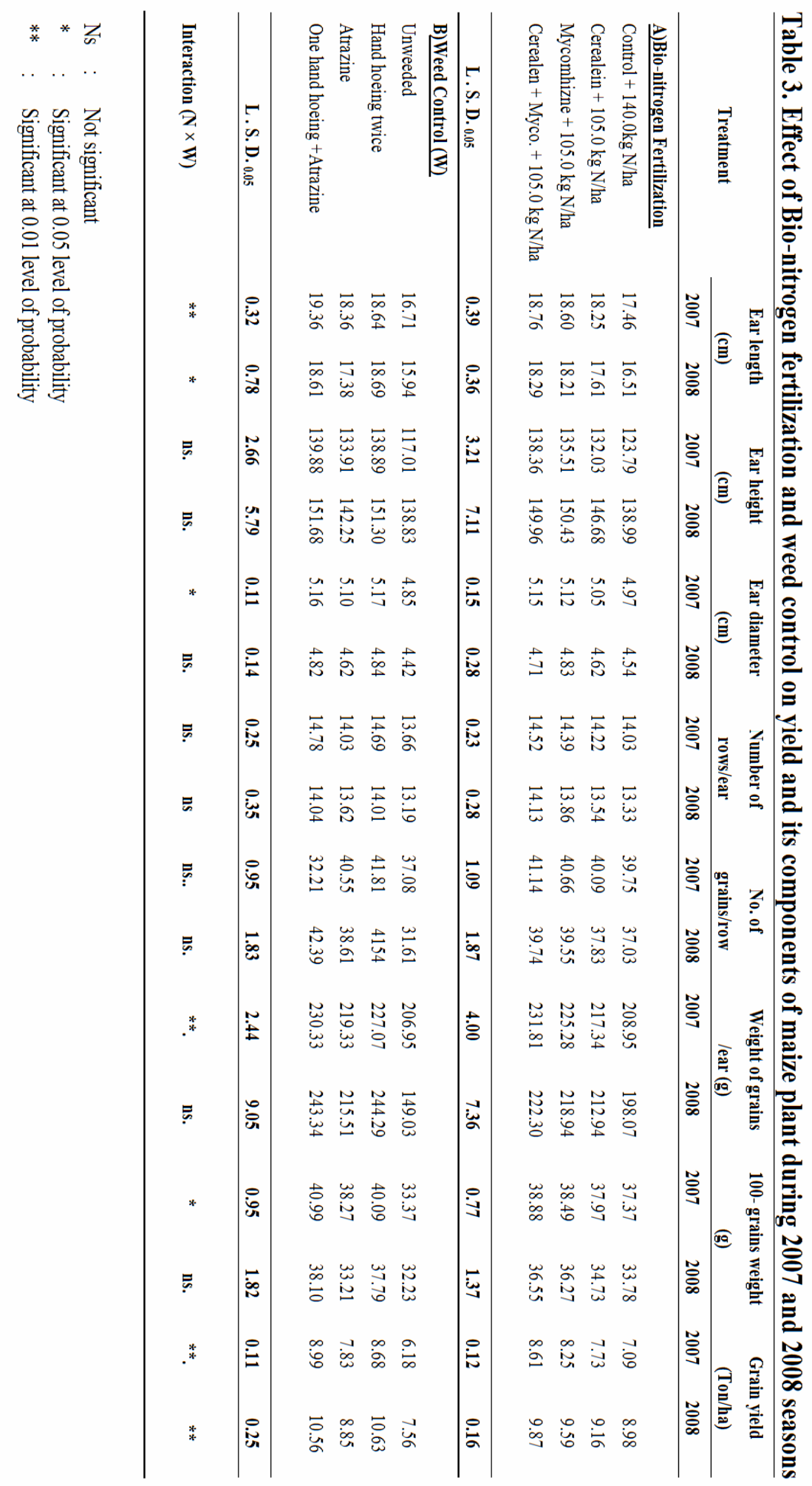




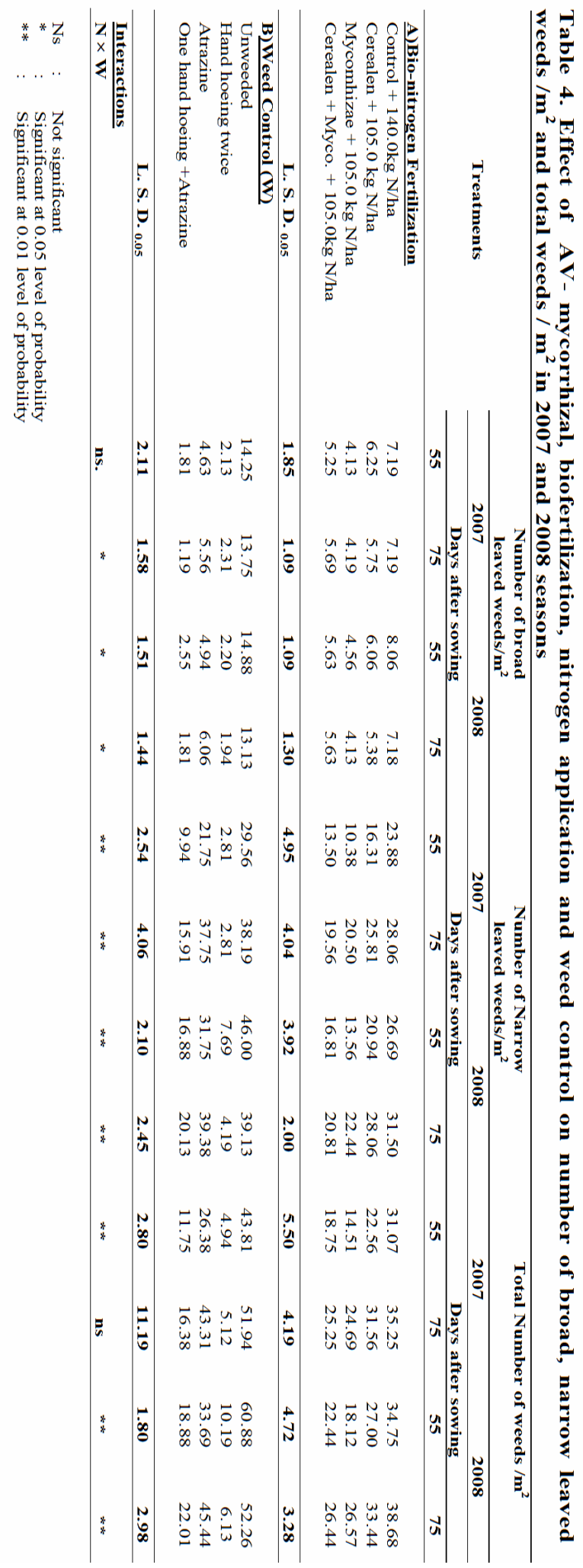




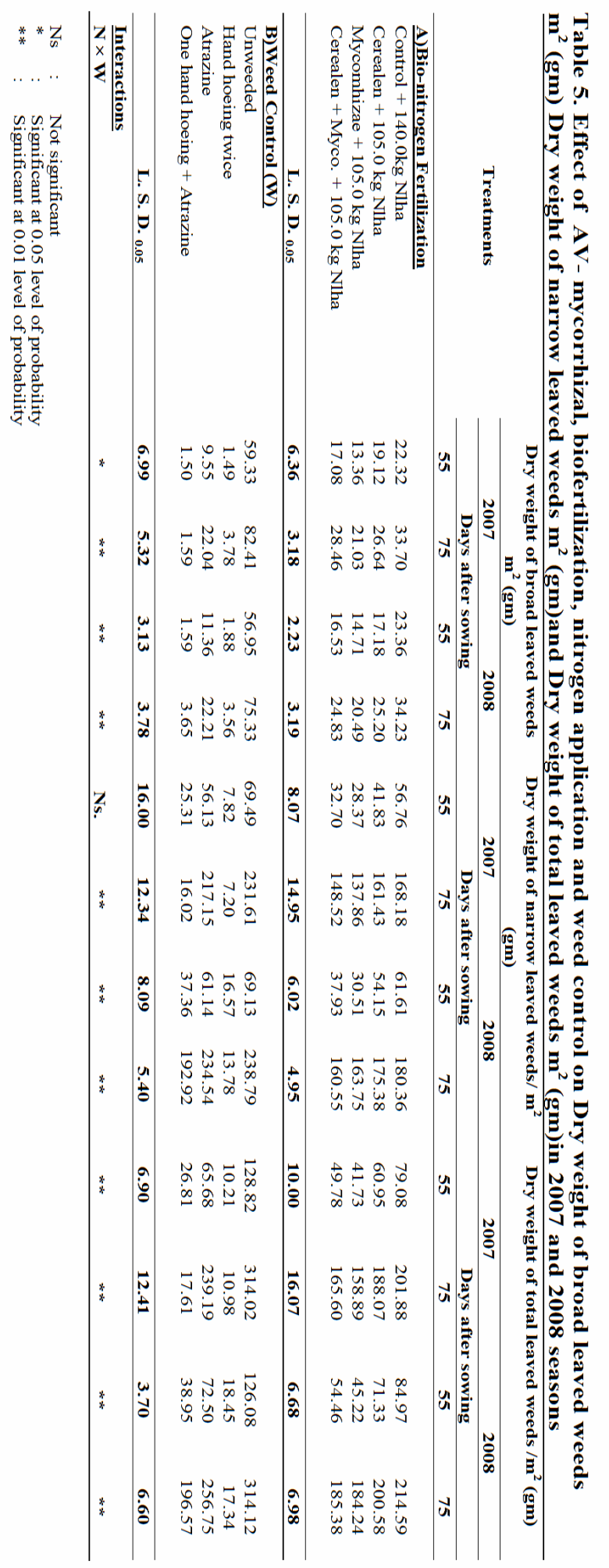




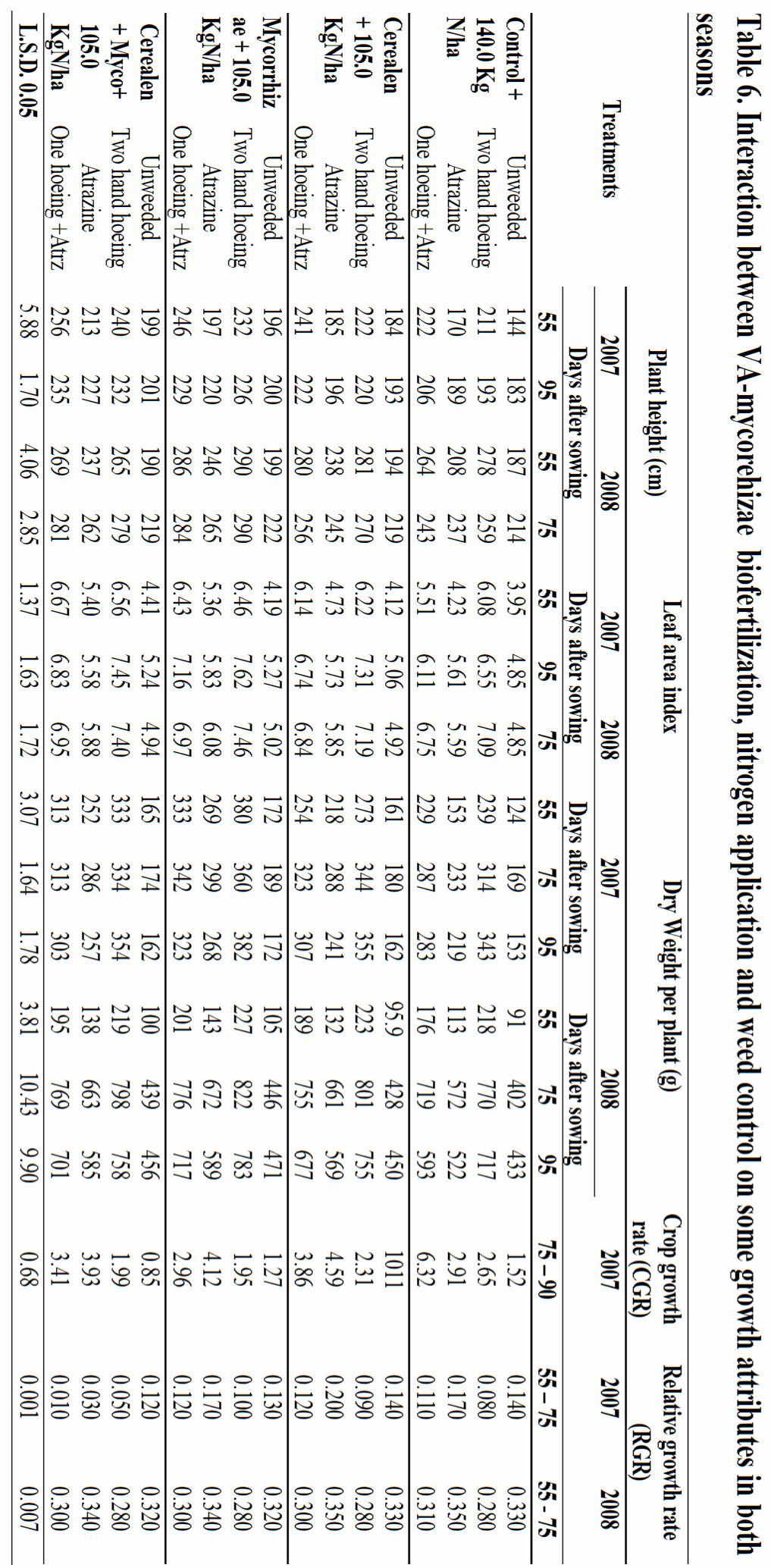




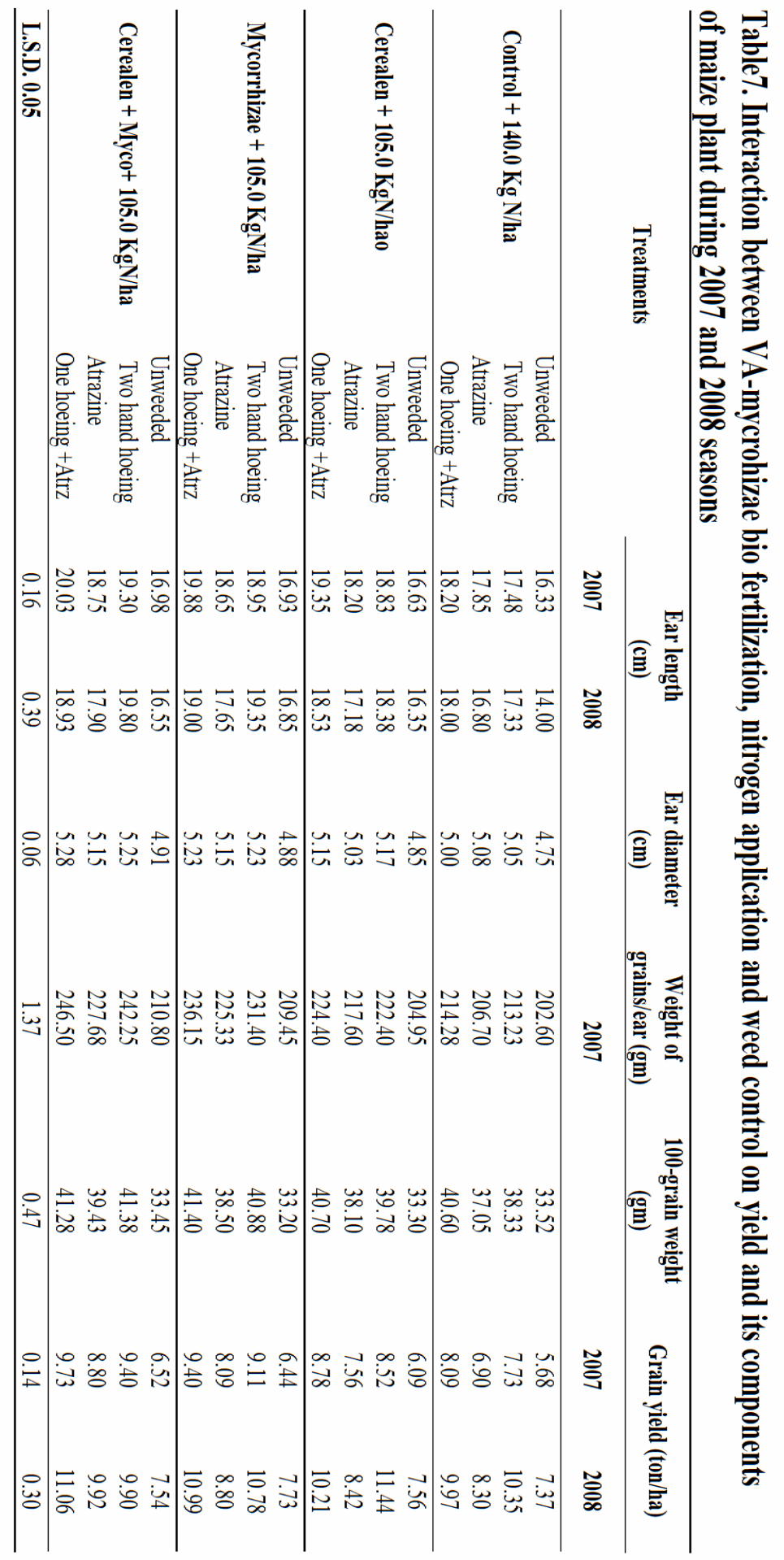




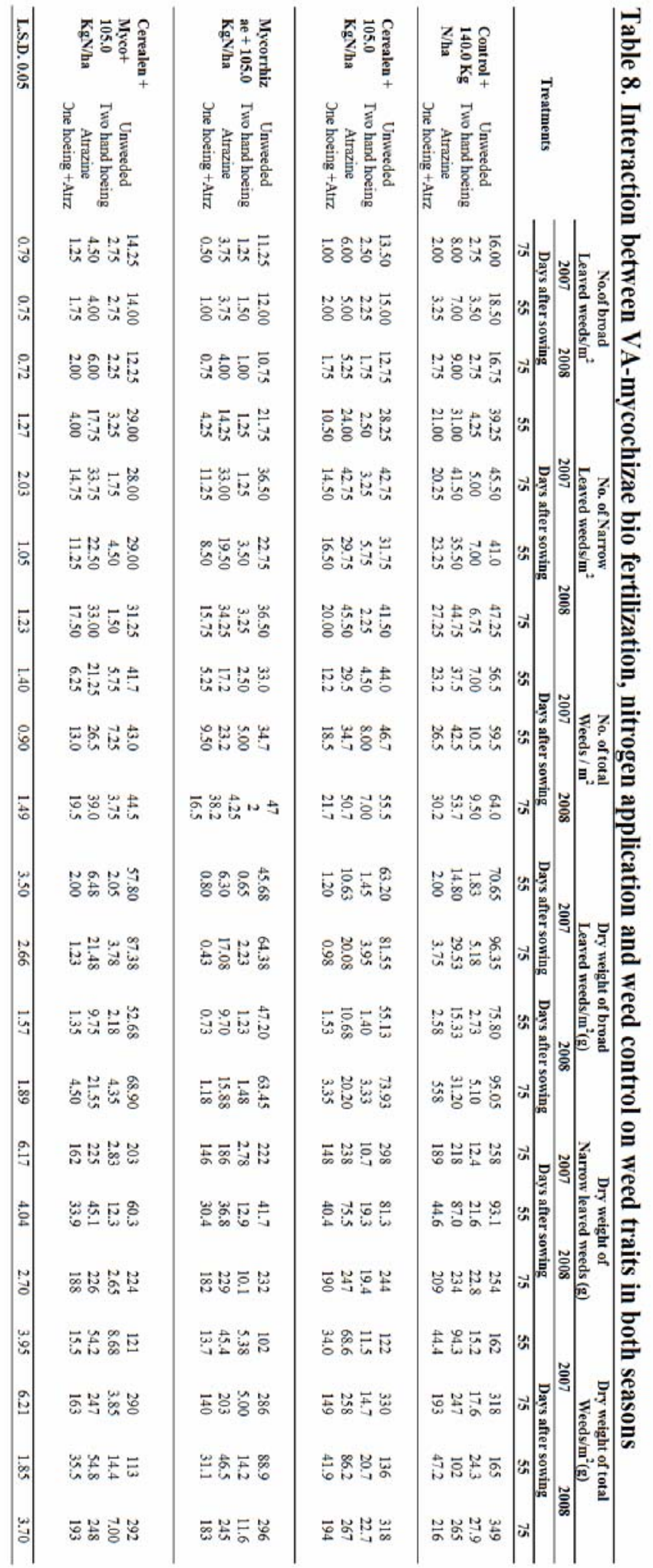


With regard to the effect of biofertilization on the total number of broad-leaved or grassy weeds and total dry weight of the same characters the obtained data indicated that there were significant differences between the three bio-nitrogen treatments in both seasons. While, the A-mycorrhizal- $+105.0 \mathrm{~kg} \mathrm{~N} / \mathrm{ha}$ significantly decreased total number of broad-leaved and grassy weeds, total dry weight of brood-leaved or grassy weeds at the two survey after sowing as compared with the unfertilized (control) in both seasons. Similar, results were reported by El-Bially (1995) and Radwan (1998).

\section{B. Effect of weed control}

Tables 1 and 2 showed that the growth attributes characters responded significantly to weed control treatments at different growth stages in both seasons. The following three treatments: atrazine + one hand hoeing; hand hoeing twice and atrazine as pre emergence herbicide had higher growth character than the unweeded treatment at three growth stages in the two seasons. These results are in agreements with those obtained by Shaban et al.. (1990), El-Bially (1995) and Mosalem and Shady (1996), while Schans and Weide (1999) and Abdel-Samie (2001) obtained maximum growth attributes by hand hoeing twice.

There were significant increases in the average of yield and its components with each weed control treatments in both seasons (Table 3$)$. The one hand hoeing + Stane gave the highest grain yield ((3.78 and 4.44 ton/ha) in the first and second season, respectively), while the untreated (control) gave the lowest grain yield. There results indicated that hand hoeing twice and a combination of pre emergence herbicides application with one hand hoeing ensure a broad spectrum for weed control over a longer period of time. To provide a long-term weed-free environment for maize, soil herbicides are applied in many cases and mechanical control and post-emergence herbicide applications are often repeated several times .Similar trend was reported by Hussein (1996), Digits (1997) and Jat et al.. (1999) who stated that yield of maize was significantly increased by hand weeding and pends methalin. Knezevic et al.. (2003) reported that band spraying with standard treatment at a half-recommended rate (atrazine 1.5 litter/fed), combined with mechanical weed control brought a satisfactory total weed reduction (83-87\%).

Average total number of broad and grassy weeds and total dry weight of weeds as affected by weed control treatments at the two growth stages are shown in Tables 5 and 6 in both seasons. All weed control treatments significantly decreased the average total number weeds and dry weight of weeds at all sampling dates compared with unweeded check. Atrazine has been used for many seasons as major herbicide for weed control in maize in the whole world. The use of atrazine as a major herbicide for maize can be attributed to the great selectivity of this herbicide towards maize composed with other herbicide used in maize field. The selectivity of atrazine in controlling weeds may be attributed to the effect of atrazine in inhibiting photosynthesis, RNA synthesis and lipid synthesis in susceptible cells but not resistant cells.

The reduction in total dry weight of weed per unit area under weed control treatment as attributed to the decrease in the number of broad and marrow leaves weeds. These results agree with those obtained by Khan et al.. (1999), Abdel-Samie (2001), Lesnik (2003), Nosratti et al.. (2007) and Abou Ziena et al. (2008).

\section{REFERENCES}

Abdel-Samie, F.S. (2001). Effect of plant population density and weed control on growth and yield of maize crop and its associated weeds. Minofiya. J. Agric. Res. 26 (1): 85 98.

Abou Ziena, F. H, J.M. El-Metwally and E.R. El-Desoki (2008). Effect of plant spacing and weed control treatments on maize yield and associated weeds in sandy soils. American-Eurasian. J. Agric. \& Environ Sci., 4 (1): 9-17.

Ahmed, M.K.A.; M.H. Afini and and M.F. Mohamed (2003). Effect of biofertilizers, chemical and or organic fertilizers on growth, yield and quality of some leguminous crops. Egypt J. of Agron. 25: 45-52.

Brown, R.H. (1984) Growth of green plant PP 153-174. In MB Tesar (eds) Physiological basis of crop growth and development. Am.Sco. Agron. Madison, Wisconsin.

Chunchun, K.; M.M. Agrawal and B.R. Gupta (1998). Azospirillum and its potential as biofertilizer. FertilizerNews, 43 (1): 47-50.

Cocking, E.C. (2003). Endophytic colonization of plant roots by nitrogen-fixing bacteria. Plant and Soil. 252 (1): 169175.

David, C.; Udensi, E. Dennis and A. Fontem Lum (2005). Evaluation of a new formulation of artrazine and metalachlor mixture for weed control in maize in Nigeria. Crop Protection, 24: 1016-1020.

Digit, A. (1997). Economics weed control methods in winter maize, Agric. Sci., Digest (Karnal). 15 (3): 143-145 (C.F. Field crop Abst. 46 (3). 1098: 155).

Dogan, N.M.; A.Ü.Nay; G. Buzz and F. Albay (2004). Determination of optimum weed control timing in maize (Zea mays L.). Turk J. Agric. 28: 349-354.

El-Bially, M.E. (1995). Weed control treatments under different density patterns in maize. Annals Agric. Sci. Ain Shams Univ., Cairo, 40 (2): 697-708. 
El-Khawas, H. (1990). Ecological, physiological and genetic studies of Azosperillum. Ph.D. Desertation, Bayreuth Univ., Germany.

El-Moselhy, M.A. and F.A. Zahran (2003). Effect of biofertilizer and mineral nitrogen fertilization on barley crop grown on a sandy soil. Egypt. J. Agric. Res. 81 (3): 921935.

Gomaa, Elham, F. (2008). Effect of Biofertilizer cerealen under different levels of nitrogen fertilization on growth, yield and Anatomy of corn plant (Zea mays L.). Egypt. J. of Appl. Sci., 23 (4A): 55-74.

Hussein, H.F. (1996). Interactive effect of nitrogen sources and weed control treatments on growth and nutrient uptake of weeds and grain yield of maize (Zea mays $\mathbf{L}$.). J. Agric. Sci. Mansoura Univ., 21 (10): 3437-3449.

Inderjit, L.K. and K.K.M. Dakshini (1997). Allelopathic effect of cyanobacterial inoculum on soil characteristics and cereal growth. Canadian J. Botany. 75 (8): 1267-1272.

Jat, R.L.; B.L. Gaur; S. Kumar and R.K. Kulhari (1999). Effect of weed management, fertilizer and rhizobium inoculation on growth yield and yield attributes of maize (Zea mays, L.) and soybean (Glycine max) under maize + soybean intercropping system. Indian J. of Agron., 43 (1) 23-26 (C.F. Weed Abst., 48 (5), 1928, 274

Khan, S.A., N. Hassain, L.A. Khan; Khan, Mand Iqbal Moqsaad (1999). Study on weed control in maize. Barhad J. of Agric., 14 (6): 581-586 (C.F. Weed Abst., 48 (6): 2372: 227).

Knezevic, M.; M. durkic, I. Knezevic and Z. Loncaria (2003). Effect of pre and post- emergence weed control on weed population and maize yield in different tillage system. Plant Soil Environ., 49 (5) 223-229.

Lesnik, M. (2003). The impacts of maize stand density on herbicide efficiency. Plant Soil Environ, 49 (1): 29-35.

Mekail, M.M.; M.A. Maatouk and I. Zanouny (2005). Efficiency of integrated nutrient supply system (INSS) of phosphorus fertilization in corn and faba bean cultivation, Minea J. of Agric. Res. Develop. (25) N (3) 405-420.

Mosalem, M.E. and M.F. Shady (1996). Effect of plant population and chemical weed control on maize (Zea mays, L.). Prohycation Proc. $7^{\text {th }}$ Conf. Agron., 9-10 Sept. 41-58.

Nosratti, J., H.M. Alizade and T. Makmasoum (2007). Evaluation the efficiency of three sulfonylurea Herbicide and their effects on maize (Zea mays, L.) Grain yield. J. Biol. Sci. 7 (7): 1262-1265.
Nofal, Fatma, A.E. and E.I.A. Mobarak (2003). Influence of manure and nitrogen on grain yield and some physical properties of maize hybrids under sandy soil conditions. Egypt. J. Appl. Sci., 18 (18 B): 497-507.

Ogut, M.; C. Akdag; O. Duzdemir and M.A. Sakin (2005). Single and double inoculation with Azospirillum/Trichoderma, the effect on dry bean and wheat. Biol. and Fert. Soils. 41 (4): 262-272.

Phillips, J.M. and D.S. Hayman (1970). Improved procedures for clearing roots and staining parasitic and vesiculararbuscular mycorrhizal fungi for rapid assessment of infection. Trans. Brit. Mycol. Soc. 55: 158-161.

Radwan, F.I. (1996). Response of mycorrhizae inoculation phosphorus and potassium fertilization on growth, yield and its components of sunflower plants. J. Agric. Res. Tanta Univ., 22 (3): 357-375.

Radwan, F.I. (1998). Response of some maize cultivars to VA-mycorrhizae inoculation, Biofertilization and soil nitrogen application. Alex. J. Agric. Res. 43 (2): 43-56.

Radwan, F.I.; A.I.A. Ebida, M.G. Torky and Hoda, H. ElKaliaf (2008). Influence of Gibberellic acid, Mycorrhizae and phosphate solubilizing bacteria on yield and chemical constituents of roselle plant (Hibiscus sabdariffa, L.). J. Adv. Agric. Res. V. 13 (2): 293-304.

Saad, O.A.O. and E.T. Ahmed (2002). Response of Leucaene leucocephala seedlings to inoculation with rhizobia, mycorrhizae fungi, chemical amendments and organic fertilization. Proc. Minia. $1^{\text {st }}$ Conf. For Agric. \& environ. Sci. Minia, Egypt.

Schans, V.D.; R.Y. Weide (1999). Strong together, weed control in maize; combine mechanical control and low application rates of herbicides, PAV. Bull-Akkerbow. (2): 9-11.

Shaban, Sh. A.; M.H. Deeb and R. El-Maury (1990). Studies on mixing some soil herbicides with nitrogen fertilizer in maize. I-weed growth. Egypt. J. Agron. 16 (2): 159-178.

Snedecor, G.W. and W.G. Cochran (1982). Statistical Methods. The Iowa State University Press. $7^{\text {th }}$ Edit. $2^{\text {nd }}$ Printing, 507 PP.

Soliman, M.S.M.; A.A. Abdel-Aziz and R.A. Derar (2001). Effect of nitrogen rate, farm yard manuring and biofertilization on growth, yield components of maize (Zea mays, L.). Egypt Sci. 16 (7): 151-167.

Virendra, K. and I.P.S. Ahlawat (2004). Carry over effect of biofertilizer and nitrogen applied to wheat (Triticum aestivum) and direct applied $\mathrm{N}$ in Maize (Zea mays) in wheat-maize cropping system. Indian Journal of Agronomy 49 (4): 233-236.

Watson, D.J.(1952) The physiological basis of variation in yield. Adv. In Agron.4:101-145. 


\section{[ل}

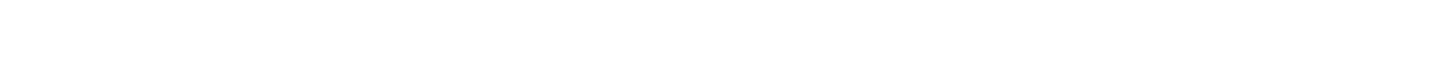

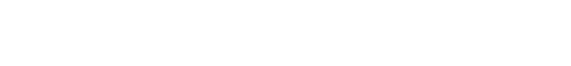

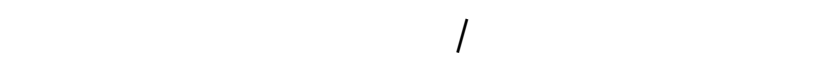

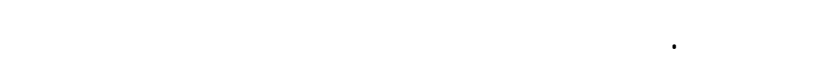

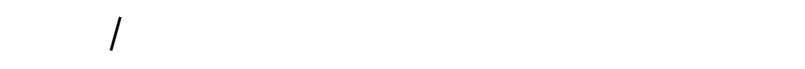

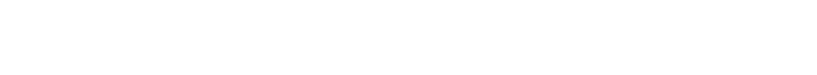

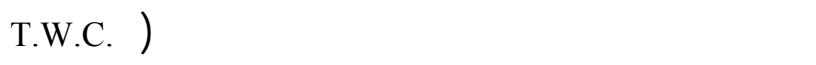

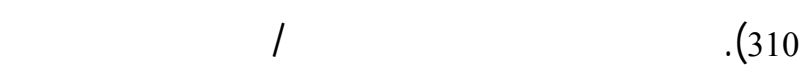

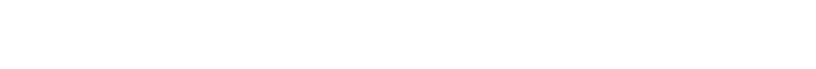
Atrazine

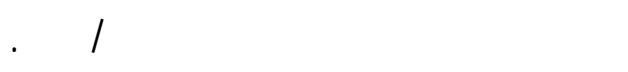

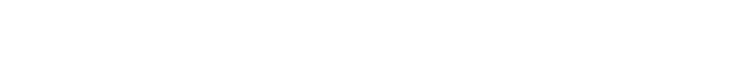

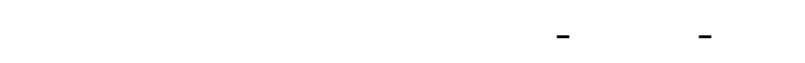

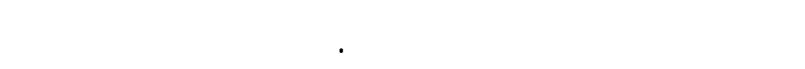

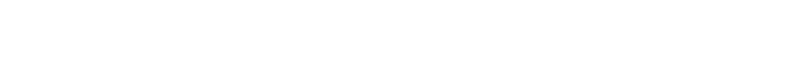

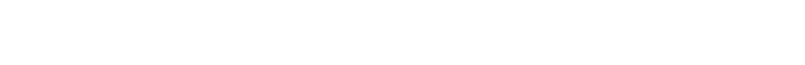
الذرة الشلمية (هجل ثلاثي (T.W.C. 310).

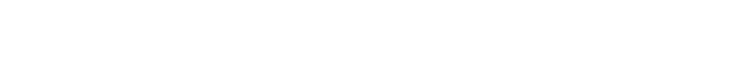

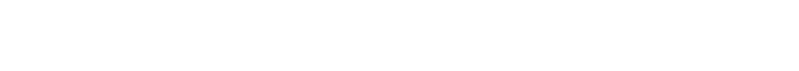

